\title{
A Conceptual Examination of Militia Movements and Challenges to Socio- Economic Development in Nigeria
}

\author{
Adebisi Kolawole Shittu \\ General Studies Department, The Polytechnic, Ibadan.
}

\begin{abstract}
The Nigeria state has for the past two decades been at the receiving end of a dramatic upsurge of militia movements. The guise of militia movements purportedly representing and seeking to protect their different group interests emerged as a result of the ethnic nationalities or religious groups perceived neglect, injustice, deprivation and marginalization within the Nigerian state. Nigerians today live in an era of militant insurgence with its grave social, economic, political and human costs. This study relies on secondary data from various sources to conceptualize the militia movement, its historical background, causative factors and implications on Nigeria's social-economic and political development. Consequent upon the threat posed by the menace of militia movements, this paper proffer possible solutions that can assist the government in tackling the insurgency of militia movements in Nigeria.
\end{abstract}

Key words: Militia movements, Ethno-religion crisis, Socio-economic development, Insurgency, National Integration.

\section{Introduction}

The historical origin of the state in the colonial era and its role in the development of capitalist production processes and relations largely shaped and defined its role in the accumulation process in the postcolonial era. The existence of the ruling class revolves around the state from which it derives its origin and wealth by employing every available means to secure power and access. Thus, the competition and struggles for state power, particularly in the economic crisis period and the post-adjustment era, heightened identity politics in Nigeria. The accentuation of identity politics is linked to the phenomenon of prolonged military rule and its institutionalization of "permanent transition" which led to increased repression of mass and popular opinions and equally increased disarticulation from the legitimacy of the state. This situation intensified different forms of identity mobilization and consciousness on the ethnic, regional, religious, communal and minority political levels (Suberu, 2004).

Identity consciousness and mobilization are often positive features of plural societies but may become counterproductive when they are employed for "discriminatory practices and unjustified use of violence". The perception of denial of rights and domination by others creates the basis for identity conflicts, with identities becoming highly politicized over the issues of control of political and economic power. The use of ethnicity for acquisition of state power and rents accruing from it has been so elevated to the centre stage of Nigerian politics that the Nigerian state has legally and unconventionally come to accept ethnicity as an integral aspect of the Nigerian project (Osaghe, 2005). The Nigerian constitution thus made provision for individual and group rights, groups interpreted as states which in Nigeria are homogenous with ethnic divisions. Thus ethnic balancing policies occupied centre stage in the power configuration and economic/social provisioning of the Nigerian state. Policies, appointments, electoral victories, and most especially rent from oil were seen from the point of view of which unit or ethnic group(s) benefits the most. The balancing policies not only increased ethnic identity consciousness, identity politics further reinforced ethnic balancing measures. Consequently group rights in Nigeria came to overshadow individual rights (Osaghe, 2005).

The adoption of the market policies of the International Financial Institutions (IFIS) otherwise known as Structural Adjustment Policies (SAP) in the 80's by the military government of Rtd Gen. Ibrahim Babangida which unleashed series of harsh measures that set the people on the part of poverty further reinforced and intensified ethnic identity politics in Nigeria (Oronsaye and Igbafe, 2012). State shrinkage and oppressive policies resulting from the emergent market policies and norms further strengthened ethnic identity politics and the quest for independence by many of such groups. It is within this period that most militia groups were born. The activities of militia movements have not only queried the citizenship question in Nigeria but have continued to challenge the rationale behind the corporate existence of the Nigerian State. Militias create identity dilemma for the group whose interests they claim to protect. It is against this backdrop that this paper interrogates the concept of militia movement vis -a -vis group/ethnic rights and identity in Nigeria. It seeks to find explanation for the resurgence and persistence of ethnic militia politics in Nigeria, most especially how the power configuration in Nigeria has intensified the phenomenon. This study shall discuss the activities and tactics of militia as separatist movement and the rationale behind their demands. 
The paper examine the excesses of militia movements, their emergence and destructive tendencies in Nigeria which have made parts of the country a terrain of conflict, violence and crime. In this paper, an attempt is made to bring to the fore the potential threat the militant groups pose to Nigeria as a sovereign nation-state.

\section{The concept of militia movement/group}

There are various definitions of militia movement by different scholars that can be used to pick out the common threads upon which the initial outlines of a conceptual framework could be based. Schneckener defined militias as "irregular, paramilitary combat units that aim at protecting and defending the interests of the government and/or certain sections of the society (Schenekener 2009:9), while Okunmu and Ikelegbe argue that a militia is, "an armed force of ordinary persons... an armed faction engaged in combat or fighting or that resorts to violence to attain certain objectives" (Okumu and Ikegbele 2010:4). Adejumobi (2002)and Badmus (2006) emphasized the preponderance of youths, coupled with the use of violence to secure largely ethnically-based self-determinative and parochial interests; while (Sessay., 2003) noted militias' lack of anchoring in formal governmental structures in terms of authority to act militarily or use military equipment or obtaining formal military training. Okumu and Ikegbele (2010:4) also posited that militias are clandestine forces.

$\operatorname{Tar}(2005)$ argued that state or society-centric definitions like those outlined above are inadequate and proposed that a holistic perspective which combines of the two might be better since it is "hybrid", "descriptive", "contexts specific and interrogates the" "agency" of both "state and non-state actors." It also assumes that although the modern state more or less controls the use of force, militias have ability to challenge its legitimacy (Tar 2005:1 '43). Such a perspective construes militia as, “....complex phenomenal that transcend simplistic formal/ informal and state/non-state dichotomies-as demonstrated by the experience weak or failing states, especially conflict prone, war torn, post-conflict and transition societies" (Tar 2005:140). In this way, militias might include certain "marginalized and dissatisfied" groups formed by different stakeholders, but lacking formal approval by state structure (Tar 2005; 142-43).

From the above definitions, a number of generalizations can be made. Militias spring from state, nonstate and societal processes and conditions (Schenekener 2009; Sessay et al 2003; Okumu and Ikegbele 2010; Adejumobi 2002 ;), pursue sectional interests (Schneckener 2009; Okumu and Ikegbele 2010; Adejumobi 2002; Badmus 2006), are complex phenomena and cannot be reduced to state or societal processes (Tar 2005). The context, actors' agency and that of the state are important variables in conceptualizing militia (Tar 2005). Lastly, militias have several attributes like preponderance of youth, violence, and reliance on use of force (Okumu and Ikegbele 2010; Adejumobi 2002).

Despite the fact that there seems to be an emerging consensus on a general perspective of militias epitomized by Tar's "hybrid" concept, one could find the perspective lacking as it does not interrogate a number of issues pertaining to how militias are constituted, interests they serve, their legality and how they emerge on the socio-political scene (Mugisha, 2011).

\section{A critique of prevailing definitions}

The above definitions connote voluntariness on militias and their members. It is assumed that actors join these groups freely and once part of them, they act freely. Similarly, groups are assumed to emerge and act on their own, or on behalf of other social groups and political entities, but with much discretion. However, empirical evidence suggests that militias are not always "voluntarily" mobilized or constituted and magnetic (Mugisha, 2011). Where the state is involved, militias may at times be formed through manipulation and cajoling as were the cases of Amuka and Rhino militias in Uganda, Mungiki of Kenya and Janjaweed of Sudan (Mang'eni 2010; Tar 2005).

Sometimes militias are forcefully constituted by the state or private groups (Mang'eni 2010). In other cases, actors may be drawn to militias because of lack of choice or the imperative to survive. That is, they would have done otherwise, but for compelling reasons or extenuating circumstances like threat of starvation and death, generalized violence and or loss of entire families (Vlassenroot and Acker 2001). Yet, it is also true that very many actors join militias voluntarily. Therefore, a good definition needs to be attentive to varying degrees of voluntariness or actors' agency.

Formulating a hybrid concept to capture the complexity of militias is poignant given the one sidedness of state-centric and society-centric-definitions. However, the terms "hybrid" and "holistic' used interchangeably by Tar to describe militia movements are in reality not synonymous. Thus, the reader is left wondering whether the attempted definition is hybrid or holistic or both! A more substantial concern is that the concept he borrows from David Francis delivers little than it promises, owning to the fact that it shrouds a number of pertinent issues about militia groups. For instance, it does not deal with the primordial structural reality of ethnic polarization in Africa. Yet, there is no single militia movement on the continent, genuine or not, that does not explicitly or implicitly present and act in this mold. Even groups that succumb to elite capture and patronage and 
those that simply degenerate into opportunism, retain this ingredient. A good definition ought to attend to this fact, more so if it claims to be holistic.

Defining militias in term of the tools they use, their objectives (assumed or real) or membership is inadequate because it does not distinguish them from many groups like vigilantes and gangs. In order to clarify the concept, it might be better to examine how militias are constituted, how they emerge onto the scene, and whose interests they serve. Interrogating these issues might not only clarify the concept, but also shed light on the contentious question of whether militias are a manifestation of civil or uncivil society (Reno 2002; Ikegbele 2011). In other words, whether they are constituted for and are representative of the collective will of the groups and communities they purport to fight for, or are antithetical to them.

Lastly, the definitions examined do not address the fluid and flexible nature of militias or their lack of fixed group boundaries. Most militias groups are malleable, if not loose. In the course of conflicts, new alliances tend to form while old ones are broken; groups also change loyalties and or mutate in terms of composition, objectives and motives (Sofiri 2007; Kalyvas 2003). Such mutation differs from those observed in the natural progression of social groups owing to their volatility. Such high levels of variation need to be property conceptualized if militias are to be understood.

Thus, this paper conceptualizes militia movement as group of people either legitimately or illegitimately, with or without state support having their members from different stratum of society and holding on some kinds of ethnic, political and religion ideologies which they intend to achieve in any way available to them but mostly resolve to violent means as the last option of achieving their objectives. Militia is a form of private army whose members live a military life that is subjected to almost the same discipline and training as soldiers. They wear uniforms and badges and always ready to meet their perceived enemy with weapons in physical combat. There are two categories of militia, that is, the "active army" who are always ready for confrontation and secondly the "reserve" who are less confrontational (Okumagba, 2009).

In Nigeria, the most visible forms of militia are ethnic and religion based militia movements. They can be described as extreme forms of ethnic and religion agitation for self determination. An ethnic or religion group assumes militant postures and gradually changed into militia groups which depend on ethnic or religion identity and seem to act as machinery through which the desires of their people are realized. The common features of the ethnic and religion militia are; the resort to violence; a preponderance of youth membership and an ethnic or religion identity affiliation (Oronsaye and Igbafe, 2012).

\section{Historical background of militia movements in Nigeria}

The emergence of ethnic militia movement in Nigeria can be viewed from one perceived notion or another which the ethnic nationalities feel they have suffered in the Nigerian state. Almost all ethnic groups talk about marginalization and domination. The Yorubas complaint of power exclusion; the Igbos of marginalization; the Niger-Delta people of exploitation and environmental degradation; Hausa-Fulani of uneven development; the Middle- Belt people of internal colonialism. Thus, everybody is requesting for empowerment on the basis of one assumption - Xenophobia (Ajayi, 2007).

Ethnic Militias featuring in Nigeria polity in 1990's comprises primarily of youths set up to provide local security outputs to their immediate communities (Vigilante Service) or as a means of protecting social, economic and political welfare/interests of their respective ethnic domain. Some of the ethnic groups fight and struggle for recognition, some for relevance while others for resource control. These struggles have prompted the use of various means in the realization of their objectives. In order to achieve their objectives, they come together to form a cohesive body hence emergence of ethnic militias in Nigeria (Thorning, 2005).

The various ethnic militias have different histories and goals. Their objectives range from drawing attention to the perceived marginalization of their ethnic group; serving as social pressure to influence the structure of power to redress perceptions of marginalization of their group or the extreme goal of outright disintegration from the Nigerian state. The ethnic movement believes in violence as means to furthering their parochial interests. These Militia groups can be found in all regions of Nigeria, but the most organized are the Movement for the Actualization of the Sovereign State of Biafra (MASSOB) and the Bakassi Boys in the Southeast; the Egbesu Boys and the Movement for the Emancipation of the Niger Delta (MEND) in the oilproducing Niger-Delta region; the Movement for the Survival of Ogoni People (MOSOP) in the south-south, the O'odua People's Congress (OPC) in the South-west and the Hisbah group and the Boko Haram in the North. Other less organized but dangerous groups are the Yandaba group in the North-west and the ECOMOG Boys in the North-east involving in most religious and political clashes (Nigeria first, 2006).

The Movement for the Actualization of Sovereign State of Biafran (MASSOB) found in 1999 is an Igbo dominated ethnic movement. Since the end of the civil war in 1970, Igbos feel completely alienated from the Nigerian state. Obianyo (2007) explains that marginalization entails "the apparent deliberate exclusion of any particular group(s) by other similar group or groups from either having access to and or taking due possession of common key positions and common resources as manifested in the political, economic, military, educational, 
media and bureaucratic realms." This is the feelings of people in Igbo society hence the quest for an Igbo state MASSOB is the body that was established to actualize this objective.

The O'odua People's Congress (OPC) is predominant in the Yoruba area and predates the return of democracy in 1999, but became more visible thereafter in their quest for a repositioned Yoruba nation in the politics of Nigeria. The O'odua People's Congress (OPC) was formed in 1994 in the wake of the crises aftermath the cancellation of the June 12, 1993 Presidential elections. At the beginning, the OPC aimed at working towards the unity, progress and autonomy of all descendants of Oduduwa (Yoruba) but in 1999, the OPC changed its major objectives from seeking self-determination for Yoruba people to crime fighting activities and settlement of personal disputes. This change in focus enlisted the OPC among the other militia groups in the country known for violence and crime.

In the Niger-Delta, the Movement for the Survival of Ogoni People (MOSOP) founded in 1990's, sparked the formation of loose armed groups that are based in that region such as the Niger-Delta People's Volunteer Force (NDPVF) and the Movement for the Emancipation of Niger-Delta (MEND). These organizations are not only struggling to call attention to the plundering of the environment of the delta due to oil exploration, but also demanding that a good proportion of the resources exploited from their region be retained there so as to right the wrong years of deprivation (Amnesty International, 2009). MEND, Egbesu Boys which is the military wing of the Ijaw National Congress and others are the armed militias in the Niger Delta that regarded themselves as capable of assuming the responsibilities of the armed forces and providing the needed security for the oil multinationals in particular and the region in general. Armed militias, bands and gangs in the region have been known to engage themselves in inter-communal and ethnic wars, struggle over leadership, the sharing of profit and compensations and for space or territory in illegal oil trading (Ikelegbe, 2005).

In the northern part of the country, religious and ethnic wars are mostly carried out by militants of the different ethnic groups. The most dominant and dangerous of these militant movements is the 'Hisbah' group and the 'Boko Haram' while other less notorious groups are the ECOMOG Boys in the North-east and Yandaba group in the North-west. The Hisbah groups are Islamic Vigilante in the predominantly Muslim states of the North that have adopted sharia legal system. The major purpose of setting up the group is to safeguard the society from deviance, protect the faith and ensure the welfare of the people in both religious and worldly manners (Al Islamy, 2003). Like their counterpart in other regions, Hisbah digressed from the objectives of its formation to now specialize in causing menace and mayhem in the society. They use dangerous weapons like bows and poisoned arrows, guns and explosive devices to carry out various conflicts and terrorize the general public.

Boko Haram is another militia group formed in 2004 and found mostly in the North eastern Nigeria. It is an Islamic sect opposed to western education. Boko Haram which comprises religious fundamentalists seeking for the adoption of sharia and abandonment of western education in the region has often leaves behind sad stories and scaring scenes of destruction, maiming and death whenever the group operates. The trial and subsequent failure of the group to enthrone Islamic sharia code and abolish western culture in the states of the north due to the outright rejection and resistance from the states is responsible for a series of crises in the region (Adagba et al, 2012). The Boko Haram sect carries out their activities with absolute disregard for the rule of law and fundamental human rights of the citizens. The group is a ready-made tool for desperate politicians to unleash attack on their perceived political enemies. Serial killing, assassination, bombing and gangsterism have become the order of the day and Nigeria is now perching on the abysmal abyss of a despicable disaster (Oronsaye and Igbafe, 2012).

\section{Conceptualizing the factors responsible for the emergence and proliferation of militia movements in Nigeria}

The explanations for the growth of militia movements in Nigeria varied. Babawale (2001) attributes the emergence of militia groups in Nigeria to imperfections in the federal system. He opines that the emergence is due to the manipulation of ethnicity by the governing elites across the various geo-political zones. Consequently, the militia groups were formed as a result of mismanagement of ethnic grievances by the Nigerian states and were meant to be the machinery for expression of defiance against oppressive rule. The formation of the ethnic militia can also be ascribed to the neglect by government or perceived neglect on the part of many ethnic groups in Nigeria. Stewart (2008) opines that neglect by government or even perceived neglect can be capitalized on by those groups who are not in government to bring up ethnic sentiment which usually lead to communal clash. This reason resulted into the establishment of the O'odua People Congress (OPC), Movement for the Survival of Ogoni People (MOSOP) and the Movement for the Actualization of Sovereign State of Biafra (MASSOB).

It must be cleared that the emergence and proliferation of militia movements cannot be caused by a single factor. Notwithstanding, the major factor responsible for the emergence and proliferation of militia movements in Nigerian state is the perception by the elites of the various ethnic groups who believe that the 
structure and operations of the Nigerian federal state has failed, thus their interest and ethnic aspiration could not be accommodated and taking care of. Fasheun (2005) opines that the military administration during their subjugation did a lot of havoc by disrupting all the platforms for expressing social discontent. The various pressure groups, trade unions and associations were either proscribed or outlawed consequently leading to the illusion of national integration and unity thus making the various ethnic nationalities to look inward and decided to form a social platform in which their divisional interest could be articulated.

Similarly, Fawehinmi (2003) believes that the emergence and proliferation of ethnic militia movements was as a result of perceived injustice, deprivation and marginalization of some ethnic groups. He contended that militia movements developed in Nigeria because of perceived exclusion and perceived injustice of various forms such as political injustice, ethnic marginalization and economic exclusion in form of access to social services. Militia movements are products of several reasons, several areas of misgovernance in Nigerian state .OPC developed as a result of dastardly and illegal cancellation of the June 12(1993) election, the Bakassi Boys emerged as a result of insecurity in the east, the APC because the Northern leaders inability to improve the quality of life of their people who are mostly poor while the Egbesu Boys results from depressing situation in the Niger Delta.

Thus, it is understandable that the collapse of basic social institutions, inter-ethnic inequality has stimulated the various ethnic nationalities to establish new organizations that would promote the interests of their ethnic groups. From this, the various groups have gained strength from the new global recognition of 'ethnic self-determination' as an integral part of the promotion of global human rights (Agbu, 2004).

More so, government should be blamed for the emergence and proliferation of ethnic militia movement because of its failure to satisfy the welfare needs of the masses and its failure to provide security of lives and property. The devastating condition of the state institutions set up to protect the lives and properties of the people especially the Nigeria Police Force is a contributory factor to the establishment and proliferation of the ethnic militia movements in Nigeria. Fawehinmi (2003) opines that the abysmal failure of the security agencies in Nigeria is responsible for the strength and social acceptability of militia movements in different parts of the country. The failure of the Nigeria Police to provide security for the public makes them to transfer their confidence in the police to ethnic militia who in most instances proved to be reliable and effective in providing security to local populace.

The growth and increase in the nation's youth as a result of the rapid population growth in the country is another factor responsible for emergence and proliferation ethnic militia. Ibrahim (2005) describes the situation as 'an extraordinary youth crisis.' This crisis is responsible for the collapse of the educational system, the limitation of opportunity in the formal job sector and subjection of the youths to the harsh conditions in the informal sector or the nightmare of an overcrowded job market. Under these circumstances, increasing numbers of youth especially in urban centres were exposed to street living and culture of marginality responsible for drug addiction, loose morality, violence, profanity and disrespect for societal values and norms (Ibrahim, 2005)

The proliferation of small arms and light weapons has increased the culture of violence and encourage disaffected groups into mounting direct challenges to legitimate authorities. Okumagba (2009) observes that the ease with which light weaponry circulates in Nigeria society is responsible for the proliferation of armed ethnic militia whom without any regard for the state owned law enforcement agencies carry on their activities. It is not a gain saying that the criminal gangs operating in many urban cities and militia movements in various parts of the country are presently in custody of large proportion of small arms and light weapons.

\section{Implications of the militia groups activities on Nigeria's socio-economic development}

The activities and actions of militia movements now pose a major threat to national security, law, order, peace and tranquility. They now engage in various vices ranging from acts of terrorism to violence, assassination, kidnapping/abduction, extra-judicial killing etc. Their mode of operation has driven fear down the spines of innocent, defenseless and well-meaning Nigerians (Oronsaye and Igbafe, 2012). They have become pawns in the hands of desperate politicians who have taken undue advantage of youth restiveness in the country. There are a number of active and inactive militia groups in Nigeria. The activities of militia in Nigeria have gradually turned the daytime into darkness; where violence, assassination, conflicts and other crime related happenings are on the increase. Today, Nigerians live in perpetual fear of militia causing grave social, economic, political and human cost (Ajala, 2006).

The menace of militia has led to the problems of uncertainties, uneasy calm, threats and potential threats which have befallen the Nigerian society and made the citizens of Nigeria to go about their day to day activities with fear and trepidation. The fear of not knowing when or where the next attack would be; the fear of not knowing when/where the next bomb would go off or who would be next to be kidnapped/abducted or when/where the next communal/religious crisis would erupt or when the next politician is assassinated (Oronsaye and Igbafe, 2012). Generally, the fear of who would be the next to be victim of circumstance. Ordinarily, it is impossible to have darkness during the day except there is an occurrence of a solar eclipse. And 
this eclipse occurs mostly once in a life time and usually lasts for only a few minutes. What is being portrayed here, is a situation where the uncertainty and fear brought about by the unwholesome activities of ethnic and religious militias have taken the God-given light (daytime) and replace it with darkness (artificial) causing people to tread with fear/caution during the daytime as though they were dealing at night. A situation where gangsters have become supreme; where orders have to "disorder and terrorism has become the norm..."'(Orobator, 2005). However, it should be pointed out her that nearly everybody abhors violence in whatever form or manner. But the haste with which the security agents and indeed the federal government hold militant groups responsible for any criminal act(s) without adequate investigation calls for a rethink. The danger here is that criminally-minded persons is in the society will explore the opportunity of the blanket labeling to commit heinous crimes, knowing full well that the searchlight will always be away from them.

Economically, the series of crises and counter attacks from the government are enough to scare away would be investors, especially the foreign ones. Even the local investors or those already on the ground would want to relocate to areas where they feel their investments are safe or where there is relative peace. The long term local effects of this are that more people are thrown out of job and they become ready tools for the use of militias groups. The daily occurrence of serious crimes in the communities and cities is a testimony to this (Onimajesin, 2008). The activities of the militias have resulted in a reduction of the foreign earning from oil, since there is drastic reduction in the production of crude oil, what comes in as earning has dropped thereby affecting the living standard of the people by promoting unemployment which in turn can lead to an increase in the number of crimes in the country (Amnesty International, 2009). More crimes like armed robbery and hired assassination are being committed daily because deadly arms and ammunition have found their way into the hands of criminally minded youths. Furthermore, criminals have exploited the lack of preparedness of the police, and citizens have therefore, resorted to vigilante even though they act arbitrarily and employ violence in carrying out their activities.

Every facet of economic seems to be affected. In one region crime is on the increase while in another inter-ethnic conflicts and wars are been quelled. All of which mostly are the making of militia groups in the country. Militant groups in Nigeria are known for the unconstitutional means they employ in expressing their grievances. They result to violence in drawing sympathy and attention to their plight. Thousands of diverse sophisticated assault rifles, rocket, propelled grenade, explosives and bombs are smuggled into the country. The weapon inflow empowers the communities and militias for accelerated violent conflicts. Thousands of people lose their lives annually in bloody activities of ethnic militias. Aside mindless and needless killings of innocent Nigerians, they also engage in wanton destruction of public and private property all in a bid to vent their frustration about certain issues. For instance, the series of bombings in Nigeria that are carried out by the Boko Haram sect has assumed an alarming dimension which usually resulted in loss of lives and destruction of property.

The militias and separatist movements not only challenge the authority of the Nigeria state as the only body with legal or legitimate control of instrument of coercion but detract from it the loyalty and obedience that should accrue to it from her citizens. Thus the Nigerian citizens are torn between loyalty to the Nigerian state and loyalty to the in-group movements manifesting today as ethnic militias. Forced to choose between the two, loyalty to the primordial groups supersedes loyalty to the Nigerian state. To many Nigerians, Nigeria is still kept together by what each group feels it can still get from it in the accumulation process and not by virtue of any legal or psychological identification with its aspiration and goals as a nation. Thus where and when any group's access to this accumulation process is denied or curtailed, a phenomenon popularly known in Nigeria as marginalization, the group threatens to secede (Obianyo, 2007). In 2010, Muhammar Gaddafi of Libya posited that the solution to the unending crisis in Nigeria is a division of the country on the religious and ethnic basis (Nigeria National Assembly, 2010). Despite the condemnation and criticism that follow this utterance, last year United State of America issued a warning that Nigeria may likely disintegrate in 2015 if the incessant ethnoreligion crisis is not curbed

The political future of the country is being threatened by the activities of these militia groups because the various ethnic nationalities that make up the country are relating to one another with every bit of suspicion, while the international community is also scared of associating with the country for fear of being labeled as supporting one group against the other and its attendant consequence on their economic interests in the country.

\section{Recommendation}

Having discussed the implications of the activities of ethnic militias on the social-economic development of Nigeria, it is pertinent that all stakeholders should embrace peace by looking at the issues that are militating against Nigeria coexistence. The first step to ameliorate the incidence of ethnic militancy is a good democratic system that would attain the goals of peace and security focused on the citizens. Building reliable democratic process to accommodate all political affiliations would be a welcome development in Nigeria because of the diverse ethnic, religious and multicultural interests. For such process to be acceptable and for the 
people to have confidence in the political system, the system must give room for elections to be transparent, open, fair, encourage equal participation, accountability to the citizens and devoid of marginalization of any ethnic groups (Iduh, 2011). It should be noted that Boko Haram insurgency is more political than religious.

Leadership comes with accountability; Nigeria leaders should transform economic wealth and distribute the state resources meaningfully to change the lives of the governed. Leadership should be accepted as service to the nation and mankind and not opportunity for personal wealth or enrichment, makes citizenry central to development while the nation should be built on the principle of rule of law and order.

The lapses and void in the security sector were exploited for creating vigilante groups that purportedly claimed they came into existence to protect the people but later metamorphosis into militancy movements. The Nigeria Police should be reformed for effectiveness. The Police should be trained to combat crimes, prevent and quell internal conflicts and urban violence rather than the use of the Military. Police officers should enjoy good salaries, conditions of service, well equipped with arms and logistics and should be psychologically and morally motivated. The Nigeria Police should draw programmes on how to combat proliferation of small arms and light weapons in the hands of the militia groups and miscreants.

The plight of the minority groups on economic and political marginalization and social inequalities should be urgently addressed by the government. The injustice of the past should be corrected while none of the ethnic groups in Nigeria should see ascend to the position of President as their exclusive right. Angaye (2002) opines that the "Accusation and allegations of neglect, oppression, domination, exploitation, victimization, discrimination, marginalization, nepotism and bigotry are common. It is difficult to see who is marginalizing who in Nigeria because all ethnic groups, from the big Hausa, Yoruba and Igbos to the small Ogonis, Ikwerres, Igalas etc. are complaining of marginalization." It is on this premise that many have called on the government to convene a "Sovereign National Conference"; a term that connotes that Nigeria should discuss how to coexist as people and live together as a nation. In the opinion of the author, National Conference would be better suggested as no government will be ready to surrender its sovereignty to any conference of people but the decisions of such a National conference should be binding on the government possibly through the conduct of a Nation-wide referendum.

Youth empowerment programmes should be exploited by the government to rechanneling their energy away from violence and militancy. Education is the bedrock of any society that wants to leap into future greatness; this is because education breads enlightened citizenry with bright ideas and initiatives to develop the country, run the future government and create self-empowerment. Such empowerment could increase the Gross Domestic Product (GDP) for the country and create a multiplier effect in the Nigerian economy. Knowledge and empowerment will save the youths from social vices and unnecessary manipulations by the politicians for conflicts and to settle bitter-political animosity as a result of joblessness (Iduh, 2011). Incessant industrial actions in Nigerian educational system should be discouraged while the efforts on Almajiri education should be intensified to remove youths who are combating tools for political elites in the Northern region from the streets to the classrooms.

The government should map out feasible strategies and agenda for peace, reach agreement with visible militant groups without reneging on the existing ones, work on the social institutions, provide infrastructure and develop existing capacity of local groups so as to build trust and confidence of people in itself. Poverty is violence and structural violence kills faster than bullets. People of Niger-Delta deserves access to justice and equitable distribution of resources beneath their own feet, the internal deprivation of the masses in the Northern region should be addressed while the relative deprivation in the south-west and south-east should also be given urgent attention in-order to curb the menace of militancy.

The strategy adopted by the federal government when declaring the state emergence in the three states of Adamawa, Bornu and Yobe by not removing the elected political office-holders in those states is commendable but military operations in the region should be given human face as lessons of Odih town incidence is still fresh thus the gross violation of human rights of Nigerians by the military operatives on counter insurgency mission should be curbed. The law enforcement agents saddled with the responsibility of internal security should be prepared to urgently take over the counter insurgency operation from the military.

\section{Conclusion}

The fundamental argument of this paper is that the character of the Nigerian state, that is, the pattern of its construction and composition, its power structure, the parochial behaviour of its hegemonic ruling class, particularly the politics of exclusion played along the line of ethnicity, the non-chalant attitude of the state to the welfare and well-being of the citizens, state centred corruption, injustice and the present market norms that nourishes rather than reduce or eliminate poverty account largely for the emergence of ethnic militia in Nigeria. The grievances that led to the resuscitation of separatist agitation in Nigeria borders on inequity in the distribution of power, economic and other social resources of the Nigerian state (Obianyo, 2007). 
In a plural society like Nigeria, conflicts and rivalries are bound to arise and these conflicts point out the society's fault lines and areas that require redress. Against this backdrop, Nigeria has witnessed incessant interethno-religious or communal conflicts, and wrangling by marginalized minorities or expression of grievances by different militias representing their groups because of the denial of certain rights accruing to them. The greater the sense of justice, fairness and equity in a society the more that society will enjoy stability, harmonious coexistence, sustained growth, loyalty, unity and national integration. This will invariably reduce to minimum extent if not entirely the menace of militia movements.

\section{References}

[1]. Adagba, O., Ugwu, S.C. and Eme, O.I (2012) Activities of Boko Haram And Insecurity Question in Nigeria Arabian Journal Of Business And Management Review Vol.1, No.9.

[2]. Adejumobi, S. (2002) "Ethnic militia groups and the national question in Nigeria." Social Science Research Council. Retrieved August 22 2011, http://programs.ssrc.org/gsc/gsc quarterly/newsletter8/content/adejumobi/printable.html.

[3]. Agbu, O. (2004). "Ethnic Militias and the Threat to Democracy in Post-Transition Nigeria". Nordic Africa Institute Research Report 127, Uppsala: Nordiska Afrikainstitutet.

[4]. Ajala, A.S. (2006). “Cultural Nationalism, Democratization and Conflict in Yoruba Perspective: Focus on O'odua Peoples' Congress (OPC) In Nigeria Politics”. Studies of Tribes \& Tribal, 4(2): 131-141

[5]. Ajayi, J.O.(2007). Oodua Peoples' Congress (OPC) and Crime Control in the Lagos Metropolis. A Thesis in the Department of Sociology, submitted to the Faculty of social sciences, in Partial fulfillment for the Degree of Doctor of Philosophy, University of Ibadan, Nigeria.

[6]. Al-Islamy, I. (2003). Hisbah Institution http://www. Islamic world.net/economics/hisbah.htm.

[7]. Amnesty International (2009). Petroleum, Pollution and Poverty in the Niger Delta. London: Amnesty International Publications.

[8]. Angaye, G. (2002) Causes and Curses of Conflicts in Nigeria. THISDAY: Festival Inc. Newspapers database.

[9]. Babawale, T. (2001). "The Rise of Ethnic Militias, De-Legitimization of the State and the Threat to Nigerian Federalism". West African Review.

[10]. Badmus, I. A. (2006) "Ethnic Militia Movements and the Crisis of Political Order in Post-Military Nigeria". Journal of Social Science, 13 (3): 191-198.

[11]. Fasheun, F.I. (2005). OPC, our History, our Mission. Lagos: Inspired Communication Ltd.

[12]. Fawehinmi, G. (2003) Ethnic Clashes Erupt in Southern Oil Town: Ethno-Net Publication 02/03/2003

[13]. Ibrahim, M. (2005). "An Empirical Survey of Children and Youth in Organised Armed Violence in Nigeria". Egbesu Boys, OPC and Bakassi Boys as a case study. Children in Organised Armed Violence (COAV), http=//www.coav.org.br/publique/media/Report Nigeria.pdf

[14]. Iduh, S. (2011). "The key challenges to peace in Nigeria". In International Journal of Vocational and Technical Education Vol.3 (8) pp. $121-134$.

[15]. Ikelegbe, A. (2005). "The Economy of Conflict in Oil Rich Niger Delta Region of Nigeria". Nordic Journal of African Studies Vol. $14(2)$.

[16]. Ikelegbe, A. (2011) “The Perverse Manifestation of Civil Society: Evidence from Nigeria." The Journal of Modern AfricanStudies. 39(1):1-24.

[17]. Kalyvas, N. S. (2003) "The Ontology of "Political Violence": Action and Identity in Civil Wars" Perspectives in Politics 1:3: 475494.

[18]. Mang'eni, B. E. (2010) "Violence as A Bargaining Tool: The Role of Youths in the 2007 Kenyan Elections", African Peace and Conflict Journal, 3:2: 74-89.

[19]. Mugisha, M.M. (2011) Militia Movement in Africa: A Conceptual Examination and Reformation Accessed 5/12/2012, at http//ssrn.com/abstract $=2041763$

[20]. Nigeria First (2006). Heart of Africa: Project launched in UK. Africa Files (November, 20): http://www.africafiles.org/article.asp? ID $=136698$ This URL $=\&$ URLName $=$

[21]. Nigeria National Assembly (2010). A Plenary session. House of Representative

[22]. Obianyo, N.E. (2007). Citizenship and Ethnic Militia Politics in Nigeria-Marginalization or Question of Indentity. The case of MASSOB." Paper presented at the $3^{\text {rd }}$ Global Conference on Pluralism, Inclusion and Citizenship: Salzburg Austria. November $18.19^{\text {th }}$.

[23]. Crathrg the Nigeria: Confronting the Challenges. Boulder: Lynne Rienner, pp.61-63.

[24]. Okumagba, P. (2009). "Ethnic Militias and Criminality in Niger-Delta" in African Research Review Vol.3(3)pp.313-330.

[25]. Okumu, W. and Ikelegbe, A. eds. (2010) Militias, Rebels and Islamist Militants': Human Insecurity and State Crises in African, Pretoria, Institute for Security Studies.

[26]. Onimajesin I. S. (2008) Ethnic Militias and Criminality in Nigeria Beyond 2007: Issues, Perspective and Challenges in Nigeria Beyond 2007: Issues, Perspectives and Challenges.

[27]. Orobator, S.E. (2005)"Two Nights in One Day: Frankenstein and His Monster, Quagmire of Violence Formula". University Of Benin Inaugural Lecture Series 76, University Of Benin Press

[28]. Oronsaye, A.O. and Igbafe, A.A. (2012) Ethnic Militia in Nigeria: An Assessment of the Terrain of Conflict, Violence and Crimes in African Journal of Social Sciences Vol.2, No1 Pp.97-115.

[29]. Osaghae, E.E. (2005), "State, Constitutionism and the Management of Ethnicity in Africa". African and Asian Studies 4, 1-2: 86105

[30]. Reno, W. (2002) “The Politics of Insurgency in Collapsing States”, Development and Change, 33:5: 837-858.

[31]. Schneckener, U. (2009) "Spoilers or Governance Actors? Engaging Armed Non-State Groups in Areas of Limited Statehood", SFBGovernance Working Paper Series: 21.

[32]. Sessay, A. Ukeje, C. Aina O. \& Odebiyi, A, Eds. (2003) Ethnic Militias and the Future of Democracy in Nigeria...http://www.boellnigeria.org/documents/ethnicMilitia.pdf

[33]. Sofiri, P. (2007) "On The Militarization of Nigeria's Niger Delta: The Genesis of Ethnic Militia in Rivers State, Nigeria", Niger Delta Economies of Violence Working Papers, Working Papers: 21, Center for Advanced Social Science (CASS), Port Harcourt, Nigeria.

[34]. Stewart, F. (ed.) (2008). Horizontal Inequalities and Conflicts: Understanding group violence in multiethnic societies. Basingstoke: New York: Palgrave Macmillan. 
[35]. Suberu, R.T. (2004). “Democratizing Nigeria's Federal Experiment”. In Robert I. Rotberg (ed.),

[36]. Tar, A. U. (2005) "The Perverse Manifestations of Civil Militias in Africa: Evidence from Western Sudan", Peace, Conflict and Development: An Interdisciplinary Journal 7: 135-173.

[37]. Thorning, R. (2005). "Civil Militias: Indonesia and Nigeria in Comparative Perspective". In David J. Franscis (ed.), Civil Militia: Africa's Intractable Security Menace? Aldershot: Ashgate Publishers, pp.89-116

[38]. Vlassenroot, K. and Acker, V. F. (2001) "War as Exit Exclusion? The Formation of Mayi-Mayi Militia in Eastern Congo, Africa Focus 17: 1-2:51-77 